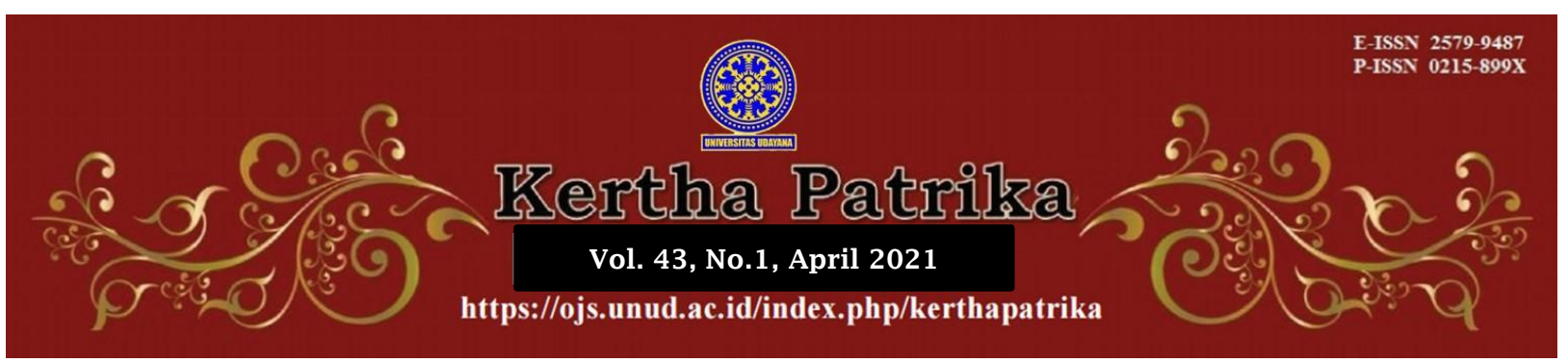

\title{
Perlindungan Keberadaan Konten Karya Intelektual Dalam Transaksi E-Commerce Berbasis Perjanjian Lisensi
}

\section{Dewa Ayu Dian Sawitri', Ni Ketut Supasti Dharmawan²}

${ }^{1}$ BernardVera Lawfirm, E-mail: dewaayu_dian@ymail.com

2Fakultas Hukum Universitas Udayana, E-mail: supasti_dharmawan@unud.ac.id

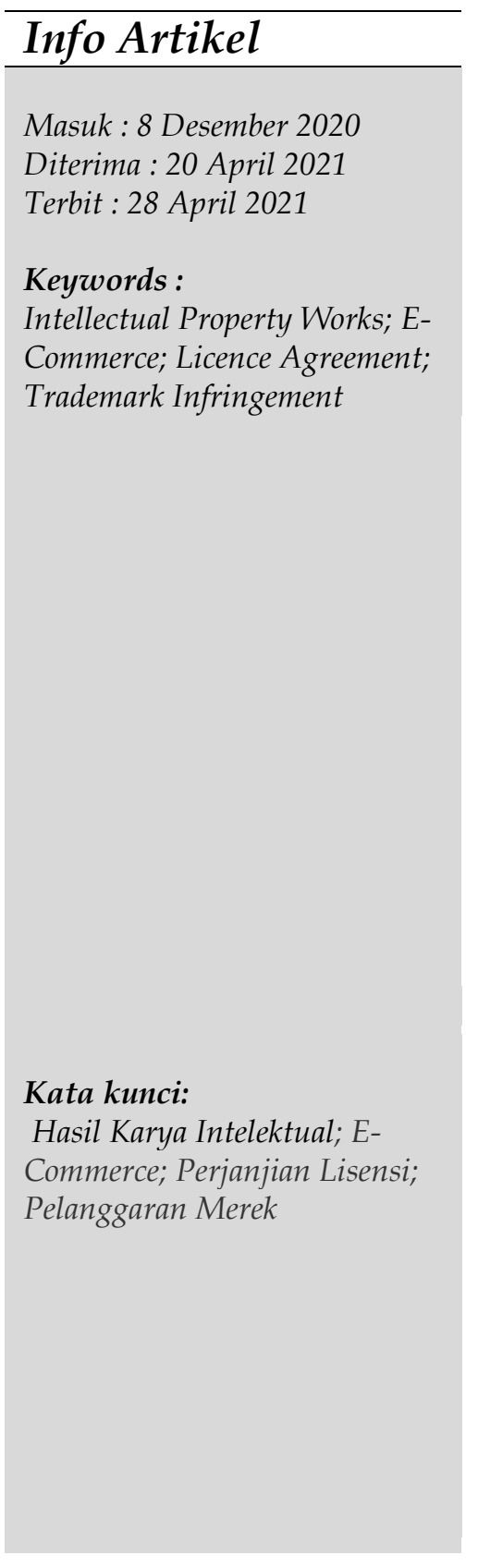

\begin{abstract}
existence of intellectual creation works such as songs is widely disseminated through electronic transactions by an entity under a certain Trademark. Spotify is one of the entities that offers a premium account that provides digital music streaming services, podcasts and videos that provide millions of songs and other content from various artists around the world based on a license agreement. However, the advanced technology makes it easier for premium content to be traded through e-commerce. This study examines the agreement model that underlies the protection of the distribution of intellectual property content including its potential violations. This study uses a normative legal research method with a statute and concepts approaches. The results of the study show that the agreement model that underlies the dissemination of intellectual work content in e-commerce transactions is a license agreement. The existence of a licensing agreement provides rights to the licensee party to use and receive protection related to the use of their economic rights. The sale and distribution of premium accounts belonging to certain entities through online shopping or e-commerce sites by unlicensed parties using certain brands such as Spotify can be categorized as a violation of the Trademark. The entity as that is harmed by the act of using a trademark without the license as well as Copyright holder for copy rights work such as song can file a lawsuit for infringement of the trademark and the copyright infringement.
\end{abstract}

\begin{tabular}{l} 
Abstrak \\
\hline Keberadaan konten karya intelektual seperti lagu banyak \\
disebarluaskan melalui transaksi elektronik oleh suatu \\
entitas dengan merek tertentu. Spotify adalah salah satu \\
entititas yang menawarkan akun premium yang \\
menyediakan layanan streaming musik digital, podcast, serta \\
video yang menyediakan jutaan lagu dan konten lain dari \\
berbagai artis di seluruh dunia berbasis perjanjian lisensi. \\
Namun, kecanggihan teknologi mempermudah konten \\
premium tersebut diperjualbelikan melalui e-commerce. \\
Penelitian ini mengkaji model perjanjian yang melandasi \\
perlindungan penyebaran konten kekayaan intelektual \\
serta potensi pelanggarannya. Penelitian ini menggunakan \\
metode penelitian hukum normatif dengan pendekatan
\end{tabular}


Corresponding Author: Dewa Ayu Dian Sawitri, E-mail: dewaayu_dian@ymail.com

DOI :

10.24843/KP.2021.v43.i01.p04

pendekatan perundang-undangan dan konsep. Hasil studi menunjukkan bahwa model perjanjian yang melandasi penyebarluasan konten karya intelektual dalam transaksi $e$ commerce adalah perjanjian lisensi. Keberadaan perjanjian lisensi memberikan hak kepada pihak yang melesinsi untuk menggunakan dan mendapat perlindungan terkait penggunaan hak ekonominya. Penjualan dan penyebarluasan akun premium milik suatu entitas tertentu melalui situs belanja online atau e-commerce oleh pihak yang tidak memiliki lisensi dengan menggunakan merek tertentu seperti Spotify dapat dikategorikan sebagai pelanggaran atas merek. Entitas yang dirugikan dengan perbuatan penggunaan suatu merek tanpa izin, termasuk sebagai pemegang Hak Cipta atas lagu dapat mengajukan gugatan pelanggaran merek dan pelanggaran Hak Cipta.

\section{Pendahuluan}

Era digital memudahkan perkembangan, penyebarluasan konten karya cipta seperti lagu, video melalui layanan aplikasi di media digital yang sangat kreatif, seperti beberapa entitas ternama Premium Spotify, Netflix, dan lain-lain. Aplikasi aplikasi seperti itu memudahkan dan mendukung berbagai karya sampai ke pengguna atau masyarakat, di seluruh dunia, global village, dunia tanpa batas melalui transaksi electronic commerce atau e-commerce.

E-commerce dipahami sebagai suatu proses dan praktik yang memanfaatkan teknologi untuk melakukan transaksi bisnis tanpa menggunakan kertas sebagai sarana mekanisme transaksi. ${ }^{1}$ Merujuk pada pemikiran Jony Wong yang dikutip oleh Ambo Aco dan Andi Hutami Endang, e-commerce adalah pembelian, penjualan dan pemasaran barang dan/atau jasa yang memanfaatkan sistem elektronik, seperti radio, televisi, jaringan komputer atau internet. ${ }^{2}$ E-commerce dapat dengan mudah dinikmati oleh para pengguna internet untuk membeli, menjual dan memasarkan barang dan/atau jasa, termasuk pula berbagai konten karya intelektual, seperti musik digital, podcast, ataupun video. ${ }^{3}$

Spotify sebagai salah satu contoh entitas layanan streaming penyedia musik digital, podcast, serta video yang menyediakan jutaan lagu dan konten lain dari berbagai artis di seluruh dunia. ${ }^{4}$ Untuk menikmati tayangan yang disediakan oleh spotify, para pengguna wajib memiliki akun berbayar dengan beberapa pilihan paket yang dapat dipilih oleh pengguna yaitu paket individual seharga Rp 49.990,00, paket duo seharga

\footnotetext{
${ }^{1}$ Mantri, B. H. (2007). Perlindungan hukum terhadap konsumen dalam transaksi e-commerce (Doctoral dissertation, program Pascasarjana Universitas Diponegoro).

2 Aco, A., \& Endang, H. (2017). Analisis Bisnis E-Commerce pada Mahasiswa Universitas Islam Negeri Alauddin Makassar. Jurnal INSYPRO (Information System and Processing), 2(1).

${ }^{3}$ Devi, K. B. T. L., \& Dharmawan, N. K. S. Tanggung Jawab Pelaku Usaha Terhadap Konsumen Terkait Cacat Tersembunyi Pada Barang Elektronik Dalam Transaksi Online. Kertha Semaya: Journal Ilmu Hukum, 4(1), 1-14.

${ }^{4}$ Spotify, 2020, Apa itu Spotify? Retrieved from: https://support.spotify.com/id/article/whatis-spotify/, diakses pada 9 November 2020.
} 
Rp 64.990,00 dan paket premium for family (selanjutnya family plan) seharga $\mathrm{Rp} 79.000,00$ yang harus dibayarkan setiap bulannya selama pengguna berlangganan spotify. ${ }^{5}$ Selama masa Pandemi Covid-19, Spotify menjadi salah satu hiburan pilihan masyarakat selama masa karantina untuk menikmati berbagai musik, podcast, dan konten-konten lainnya.

Melihat ketertarikan masyarakat untuk berlangganan Spotify, kini muncul berbagai online shop yang menjual akun premium Spotify dengan harga yang lebih murah daripada harga resmi. ${ }^{6}$ Diketahui bahwa untuk biaya resmi berlangganan akun Spotify adalah Rp 49.990,00 hingga Rp 79.000,00 tergantung pilihan paket dan jumlah perangkat yang didaftarkan, sementara para pelaku usaha online shop ini mampu memberikan harga yang tergolong lebih murah, yaitu sekitar Rp 10.000,00 hingga Rp 40.000,00.7 Fenomena ini dapat dijumpai dengan mudah pada beberapa platform sosial media seperti Twitter dan Instagram serta beberapa situs belanja online (e-commerce). ${ }^{8}$

Para pelaku usaha yang menjual akun premium Spotify ini memanfaatkan paket family plan yang disediakan oleh pihak Spotify yang menawarkan paket Premium for Family (selanjutnya family plan), yaitu suatu akun premium yang dapat digunakan bersama-sama oleh beberapa orang dalam satu keluarga dengan harga paket yaitu Rp 79.000,00 untuk 6 (enam) orang pengguna. ${ }^{9}$ Harga yang ditawarkan untuk berlangganan paket ini tentu jauh lebih murah jika dibandingkan dengan harga paket berlangganan individual yang dipatok seharga Rp 49.000,00 untuk setiap bulannya. Hal serupa juga dialami oleh penyedia layanan streaming lainnya seperti Netflix..$^{10}$

Adapun persyaratan yang harus dipenuhi oleh pihak pelaku usaha untuk dapat mengakses paket ini adalah "pemegang akun utama dan pemegang akun tambahan harus merupakan anggota keluarga yang tinggal di alamat yang sama". ${ }^{11}$ Persyaratan yang diajukan oleh Spotify tersebut dapat diinterpretasikan bahwa keenam orang yang dapat mengakses akun premium tersebut adalah orang-orang yang merupakan keluarga dan tinggal di alamat yang sama atau tinggal satu atap. Tidak adanya verifikasi alamat yang dilakukan oleh pihak Spotify ternyata menjadi celah bagi penyalahgunaan paket ini oleh banyak pengguna dengan cara membagikan akun premium tersebut ke orang lain yang bukan keluarga dan tidak tinggal satu rumah, sebagaimana yang dilakukan oleh para pelaku penjualan akun premium pada e-commerce.

Persetujuan yang diberikan oleh pihak pelaku usaha untuk dapat mengakses paket family plan yang disediakan oleh pihak Spotify dapat dikategorikan sebagai perjanjian, yaitu kontrak elektronik atau e-contract. Merujuk pada ketentuan Pasal 1 angka 17 Undang-Undang Nomor 11 Tahun 2008 tentang Informasi dan Transaksi

\footnotetext{
${ }^{5}$ Adi Fida Rahman, 2020, Cara Menikmati Netflix dari Berbagai Perangkat, Detik.com, Retrieved from: https://inet.detik.com/tips-dan-trik/d-3113004/cara-menikmati-netflix-dari-berbagaiperangkat, diakses pada 10 November 2020.

${ }_{6}$ Wahyunanda Kusuma Pertiwi, 2020, Marak Jual Beli Akun Netflix, Spotify dan Youtube Premium di Indonesia, Legalkah?, Kompas.com, Retrieved from: https://tekno.kompas.com/read/2020/06/26/13440677/marak-jual-beli-akun-netflix-spotifydan-youtube-premium-di-indonesia-legalkah?page=all, diakses pada 12 November 2020. ${ }^{7}$ Ibid.

${ }^{8} \mathrm{Ibid}$.

${ }^{9}$ Bill Clinten, 2019, Paket Family Sering Disalahgunakan, Spotify pun Minta Data Lokasi, Kompas.com, retrieved from: https://tekno.kompas.com/read/2019/09/15/11080057/paket-family-seringdisalahgunakan-spotify-pun-minta-data-lokasi?page=all., diakses pada 12 November 2020 .

${ }^{10}$ Wahyunanda Kusuma Pertiwi, loc. cit.

11 Spotify, 2020, Retrieved from: https://www.spotify.com/id/legal/premium-family-terms/, diakses pada 12 November 2020.
} 
Elektronik, kontrak elektronik adalah perjanjian para pihak yang dibuat melalui sistem elektronik. Dalam pembentukan dan penegakan hukum, khususnya yang berkaitan dengan perjanjian dikenal beberapa asas antara lain asas pacta sunt servanda, asas konsensualitas, serta asas itikad baik.

Menurut asas pacta sunt servanda, suatu kontrak mengikat para pihak pembuatnya dan mengikatnya sama dengan kekuatan suatu undang-undang. ${ }^{12}$ Asas pacta sunt servanda diimplementasikan dalam ketentuan Pasal 1338 ayat (1) Kitab Undang-Undang Hukum Perdata (selanjutnya KUHPer). ${ }^{13}$ Adagium ini diakui pula sebagai aturan bahwa semua persetujuan yang dibuat oleh manusia secara timbal-balik pada hakikatnya bermaksud untuk dipenuhi dan jika perlu dapat dipaksakan, sehingga secara hukum mengikat. ${ }^{14}$ Artinya, para pihak harus mentaati kesepakatan yang telah disepakati bersama karena perjanjian tersebut berlaku sebagai undang-undang bagi para pihak. ${ }^{15}$

Selain itu, dalam kontrak juga mengenal asas konsensualitas yaitu asas yang pada intinya menentukan bahwa untuk melahirkan perjanjian cukup dengan sepakat saja dan bahwa perjanjian itu sudah dilahirkan pada saat terjadinya sebuah persetujuan. ${ }^{16}$ Ketentuan mengenai asas konsensualitas dapat ditemukan pada ketentuan Pasal 1320 KUHPer sebagai salah satu syarat sahnya perjanjian, yaitu kata "sepakat" yang menentukan adanya persesuaian kehendak di antara para pihak dalam perjanjian tersebut.

Dalam kontrak juga dikenal adanya asas itikad baik atau good faith, yaitu perjanjian harus dilaksanakan dengan itikad baik sebagaimana ditentukan dalam ketentuan Pasal 1338 ayat (3) KUHPer. ${ }^{17}$ Dalam bahasa Belanda, istilah itikad baik dikenal dengan te goeder trouw yang sering diterjemahkan pula dengan kejujuran.18 Itikad baik atau good faith dapat dibedakan menjadi 2 (dua) macam, yaitu itikad baik pada saat akan melakukan perjanjian dan itikad baik pada saat melaksanakan hak-hak dan kewajiban-kewajiban. ${ }^{19}$

Tentu saja dalam konteks hubungan kontraktual, berbagai hubungan hukum dapat terjadi antara para pihak, dan memerlukan perangkat hukum sebagai legalitasnya. Sehubungan dengan penomena tersebut nenjadi penting untuk dikaji dan dieksplorasi permasalah hukum yang berfokus pada bagaimana model Pengaturan para pihak dalam transaksi e-commerceberbasis aplikasi layanan konten karya intelektual, bagaimana tanggung jawab pihak pelanggan yang menyebarluaskan kembali layanan konten aplikasi suatu entitas di media digital.

Penelitian ini jika dibandingkan dengan beberapa studi terdahulu memiliki kesamaan dari segi topik, yaitu sama-sama mengkaji pengaturan berkaitan dengan $e$ commerce, namun fokus kajiannya berbeda. Tulisan ini menekankan pada model pengaturan para pihak dalam transaksi e-commerce berbasis aplikasi layanan konten

${ }^{12}$ Fuady, D. M. (2014). Teori-teori Besar Dalam Hukum: Grand Theory. Prenada Media, h. 226.

${ }_{13}$ Muhtarom, M. (2014). Asas-Asas Hukum Perjanjian: Suatu Landasan Dalam Pembuatan Kontrak.

14 Sinaga, N. A. (2018). Peranan Asas-Asas Hukum Perjanjian Dalam Mewujudkan Tujuan

Perjanjian. Binamulia Hukum, 7(2), 107-120, DOI: https://doi.org/10.37893/jbh.v7i2.20

${ }^{15} \mathrm{Ibid}$.

${ }^{16}$ Ibid.

${ }^{17}$ Muhtarom, M. loc. cit.

18 Sinaga, N. A. loc. cit.

19 Ibid. 
karya intelektual dan tanggung jawab pihak pelanggan yang menyebarluaskan kembali layanan konten aplikasi suatu entitas di media digital.

Studi terdahulu dilakukan oleh C. Maya Indah pada tahun 2010, mengkaji tentang Aspek Perjanjian Electronic Commerce dan Implikasinya Pada Hukum Pembuktian di Indonesia. Dalam hal ini, fokus penelitian adalah legalitas kontrak pada transaksi e-commerce. ${ }^{20}$ Yudha Sri Wulandari pada tahun 2018, mengkaji tentang perlindungan hukum bagi konsumen terhadap transaksi jual beli e-commerce. Dalam hal ini, fokus penelitian adalah wanprestasi dalam perjanjian jual beli secara online. ${ }^{21}$

Penulisan ini bertujuan untuk mengidentifikasi, menganalisis dan mengelaborasi model perjanjian yang melandasi penyebarluasan karya intelektual melalui e-commerce serta potensi pelanggaran terkait dengan penyebarluasan karya tersebut. Mengingat perkembangan e-commerce di era digital yang tidak hanya menjual barang tetapi juga sudah mulai memperdagangkan karya intelektual, hal ini tentu menimbulkan potensi pelanggaran. Dalam rangka mewujudkan tujuan penulisan, tulisan ini secara sistematis membahas substansi yang relevan dengan fokus permasalahan. Pertama, akan dibahas tentang pengaturan mengenai model perjanjian yang melandasi penyebarluasan karya intelektual melalui e-commerce yang sesuai dengan ketentuan peraturan perundang-undangan. Kedua, akan dilakukan analisis mengenai potensi pelanggaran terkait penyebarluasan karya intelektual melalui ecommerce.

\section{Metode Penelitian}

Penulisan karya ilmiah ini merupakan penelitian hukum normatif. Merujuk pada pemikiran Peter Mahmud Marzuki, penelitian hukum normatif adalah suatu proses untuk menemukan suatu aturan hukum, prinsip-prinsip hukum, maupun doktrindoktrin hukum untuk menjawab permasalahan hukum yang sedang dihadapi. ${ }^{22}$

Tulisan ini menggunakan pendekatan peraturan perundang-undangan (statute approach) dengan mencermati ketentuan-ketentuan yang berlaku dalam Kitab UndangUndang Hukum Perdata (KUHPer) dan peraturan perundang-undangan terkaitserta pendekatan konsep (conceptual approach) berkaitan dengan konsep, teori, dan asas hukum mengenai perjanjian. Teknik penelusuran bahan hukum menggunakan tehnik studi dokumen serta analisis kajian menggunakan analisis kualitatif.

\section{Hasil Dan Pembahasan}

\subsection{Model Perjanjian Yang Melandasi Penyebarluasan Karya Intelektual Melalui E- Commerce}

Merujuk pada pemikiran Jony Wong, e-commerce dapat dipahami sebagai pembelian, penjualan dan pemasaran barang dan/atau jasa yang memanfaatkan sistem

${ }^{20}$ Indah, C. (2010). Aspek Perjanjian Electronic Commerce Dan Implikasinya Pada Hukum Pembuktian Di Indonesia. Masalah-Masalah Hukum, 39(2), 172-184. doi:10.14710/mmh.39.2.2010.172-184.

${ }^{21}$ Wulandari, Y. S. (2018). Perlindungan Hukum bagi Konsumen terhadap Transaksi Jual Beli ECommerce. AJUDIKASI: Jurnal Ilmu Hukum, 2(2).

${ }^{22}$ Fajar, M \& Achmad, Y. (2013). Dualisme Penelitian Hukum Normatif \& Empiris. Yogyakarta: Pustaka Pelajar, h. 90. 
elektronik, seperti radio, televisi, jaringan komputer atau internet. ${ }^{23}$ E-commerce memberikan kemudahan bagi para pengguna untuk dapat membeli, menjual dan memasarkan barang dan/atau jasa, termasuk juga penjualan dan pembelian berbagai konten karya intelektual, seperti musik digital, podcast, ataupun video.

Adapun salah satu model perjanjian yang melandasi penyebarluasan konten karya intelektual dalam e-commerce adalah perjanjian Lisensi. Merujuk pada ketentuan Pasal 1 angka 20 Undang-Undang Nomor 28 Tahun 2014 tentang Hak Cipta (selanjutnya "UUHC"), dapat dipahami bahwa:

"Lisensi adalah izin tertulis yang diberkan oleh Pemegang Hak Cipta atau Pemilik Hak Terkait kepada pihak lain untuk melaksanakan hak ekonomi atas Ciptaannya atau produk Hak Terkait dengan syarat tertentu".

Perjanjian Lisensi berkaitan erat dengan kewenangan dalam bentuk keistimewaan (privilege) seseorang atau pihak tertentu untuk melakukan sesuatu. ${ }^{24}$ Dalam hal ini, perjanjian lisensi memberikan kewenangan kepada pihak lain untuk melaksanakan hak ekonomi daripada pemegang hak cipta atau pemilik hak terkait dengan jangka waktu tertentu disertai dengan kewajiban untuk membayar sejumlah royalti kepada Pemegang Hak Cipta, sebagaimana diatur dalam ketentuan Pasal 80 UUHC. ${ }^{25}$

Spotify dikenal sebagai salah satu entitas layanan berbayar yang menyediakan berbagai judul lagu, podcast dan video dengan mekanisme streaming. Dalam hal ini, spotify dapat dipahami sebagai pihak yang diberikan lisensi oleh pemegang Hak Cipta untuk melaksanakan hak ekonomi dari pemegang hak cipta atau pemilik hak terkait. Sebagai pihak yang menerima Lisensi, entitas seperti spotify memiliki kewajiban untuk melindungi Ciptaan dan produk Hak Terkait yang dimiliki oleh Pencipta atau pemegang Hak Cipta, sebagaimana ditentukan dalam Pasal 2 UUHC.

Untuk menikmati layanan yang disediakan oleh suatu entitas seperti Spotify, pengguna harus mendaftarkan diri terlebih dahulu melalui aplikasi pada perangkat smartphone ataupun bisa melalui website resmi Spotify. Pada masa pandemik covid-19, kebutuhan akan hiburan membuat masyarakat melakukan berbagai cara untuk dapat mengakses layanan Spotify. Para pelaku usaha pun dengan jeli melihat peluang ini dengan menjual akun premium Spotify melalui berbagai platform media sosial seperti instagram dan twitter, serta menjual akun premium Spotify pada situs belanja online atau e-commerce. Uniknya, harga yang ditawarkan pun jauh lebih murah daripada harga resmi yang tertera pada website resmi Spotify.

Para pelaku usaha ini mengklaim bahwa usaha yang mereka lakukan adalah legal, karena mereka mengandalkan sistem berlangganan keluarga atau yang biasa dikenal dengan Family Plan. ${ }^{26}$ Sesuai dengan namanya, paket family plan memungkinkan beberapa pengguna untuk menikmati layanan dari Spotify. Harga yang ditawarkan pun lebih murah daripada berlangganan secara pribadi (personal). ${ }^{27}$ Adapun sistem yang dilakukan oleh pelaku usaha akun premium Spotify ini adalah dengan mengumpulkan

${ }^{23}$ Aco, A., \& Endang, H. loc. cit.

24 Paramarta, I. G. B. A. A., Putra, I. B. W., \& Utari, N. K. S. (2017). Akibat Hukum Perjanjian Lisensi Terhadap Pihak Ketiga. Acta Comitas: Jurnal Hukum Kenotariatan, 2(1), 75-83.

${ }^{25}$ Supasti, N. K. (2014). Relevansi Hak Kekayaan Intelektual Dengan Hak Asasi Manusia

Generasi Kedua. Jurnal Dinamika Hukum, 14(3), 518-527.

${ }^{26}$ Bill Clinten, 2020, Pengakuan Penjual Akun Premium Netflix dan Spotify, Lebih Murah dari Resmi, Kompas.com, retrieved from: https:/ tekno.kompas.com/read/2020/06/26/14521357/pengakuan-penjual-akun-premiumnetflix-dan-spotify-lebih-murah-dari-resmi, diakses pada 13 November 2020.

27 Ibid. 
beberapa pembeli untuk kemudian dimasukkan dalam sistem family atau keluarga. ${ }^{28}$ Para pelaku usaha ini menganggap tindakan yang mereka lakukan bukan suatu pelanggaran, karena akun yang mereka sediakan bukan berasal dari aplikasi Android (APK) illegal. ${ }^{29}$

Diandalkannya sistem berlangganan keluarga (family plan) pada aplikasi Spotify justru membuat para pelaku usaha ini berpotensi melakukan pelanggaran perjanjian. Pada aplikasi Spotify ditentukan secara tegas bahwa "agar berhak mendapatkan Langganan Premium Family, pemegang akun utama dan pemegang akun tambahan harus merupakan anggota keluarga yang tinggal di alamat yang sama." 30 Untuk dapat berlangganan dengan sistem keluarga, pelaku usaha yang memanfaatkan sistem ini harus menyatakan setuju dengan term and condition yang telah ditentukan oleh pihak Spotify. Dengan disetujuinya persyaratan yang ditentukan oleh Spotify tersebut, para pelaku usaha secara sadar telah sepakat untuk mengikatkan dirinya pada perjanjian dengan pihak Spotify.

Dalam ketentuan Pasal 1457 KUHPer, jual beli adalah suatu perjanjian, dengan mana pihak yang satu mengikatkan dirinya untuk menyerahkan suatu kebendaan, dan pihak yang lain untuk membayar harga yang telah dijanjikan. ${ }^{31}$ Ketentuan Pasal 1313 KUHPer juga menentukan definisi mengenai perjanjian sebagai suatu perbuatan yang mana satu orang atau lebih mengikatkan dirinya terhadap satu orang atau lebih. ${ }^{32}$ Merujuk pada pemikiran Sudargo Gautama, supaya perjanjian menjadi sah maka para pihak harus sepakat terhadap segala hal yang terdapat dalam perjanjian. ${ }^{33}$ Kesepakatan yang terjadi di antara para pelaku usaha dengan pihak Spotify menunjukkan adanya persesuaian kehendak antara tawaran (offerte) dan akseptasi (acceptatie) sebagaimana dikenal dengan asas konsensualitas. ${ }^{34}$ Dalam ketentuan Pasal 1320 KUHPer ditentukan bahwa untuk sahnya suatu perjanjian diperlukan 4 (empat) syarat, yaitu:

a. sepakat mereka yang mengikatkan dirinya;

b. kecakapan untuk membuat suatu perikatan;

c. suatu hal tertentu; dan

d. suatu sebab yang halal.

Dalam rumusan pasal tersebut, dua syarat pertama merupakan syarat subyektif dan dua syarat terakhir adalah syarat obyektif. Apabila syarat subyektif tidak terpenuhi, maka suatu perjanjian dapat dibatalkan sebagaimana ditentukan 1446 dan 1450 KUHPer, sedangkan apabila syarat obyektif yang tidak terpenuhi maka perjanjian batal demi hukum. Suatu perjanjian dapat dibatalkan berarti salah satu pihak yang terikat dalam perjanjian dapat memintakan pembatalan atas perjanjian tersebut dan perjanjian tetap mengikat kedua pihak dalam perjanjian selama tidak dibatalkan oleh hakim. ${ }^{35}$

28 Ibid.

${ }^{29}$ Ibid.

30 Spotify, 2020, Premium Family Terms, Retrieved from: https://www.spotify.com/id/legal/premium-family-terms/, diakses pada 13 November 2020.

31 Fitriah, F. (2020). Perlindungan Hukum Bagi Konsumen Dalam Transaksi Jual Beli Melalui Media Sosial. Solusi, 18(3), 371-382. https:/ / doi.org/10.36546/solusi.v18i3.305

32 Endi Suhadi. (2017). Aspek Konsensualisme Dalam Penambahan Klausula Kontrak Tanpa Persetujuan Para Pihak. Jurnal Ilmiah Hukum Dan Keadilan, 4(1), 94-109. Retrieved from https://ejurnal.stih-painan.ac.id/index.php/jihk/article/view/78

${ }^{33}$ Nurwullan, S., \& Siregar, H. F. (2020, June). Asas Konsensualisme Dalam Penambahan Klausula Kontrak Berdasarkan Prinsip Itikad Baik. In Proceedings (Vol. 1, No. 1).

34 Ibid.

35 Isnandya, E. R. (2020). Pembatalan oleh Hakim terhadap Akta Jual Beli yang Dibuat Berdasarkan Penipuan (Bedrog). Indonesian Notary, 2(3). 
Ketentuan dalam Pasal 1320 KUHPer menentukan kata "sepakat" atau "konsensualitas" sebagai salah satu syarat sahnya suatu perjanian. Konsensualitas sebagaimana ditentukan dalam Pasal 1320 KUHPer berasal dari kata "konsensus" yang berarti kesepakatan, yaitu tercapainya suatu persesuaian kehendak antara satu pihak dengan pihak lainnya yang ditunjukkan dengan kata-kata "setuju", "oke" atau lain sebagainya. ${ }^{36}$ Kesepakatan antara pihak pelaku usaha dan pihak Spotify menjadikan perjanjian diantara mereka sah dan berlaku sebagai undang-undang bagi keduanya atau dikenal dengan teori pacta sunt servanda, sebagaimana ditentukan dalam ketentuan Pasal 1338 ayat (1) KUHPer.

Dalam ketentuan Pasal 1338 juga ditentukan bahwa "suatu perjanjian harus dilaksanaan dengan itikad baik". Konsep "itikad baik" menghendaki bahwa dalam setiap pembuatan perjanjian, para pihak memiliki kebebasan untuk menentukan isi perjanjian yang dilandasi dengan adanya itikad baik yaitu tidak melanggar peraturan perundang-undangan serta tidak melanggar kepentingan masyarakat. ${ }^{37}$ Itikad baik dalam perjanjian kegiatan usaha atau bisnis dapat pula diinterpretasikan sebagai etika bisnis, yaitu nilai-nilai dan norma-norma moral yang berlaku bagi praktek bisnis. ${ }^{38}$ Secara umum, terdapat beberapa prinsip-prinsip etika bisnis, yaitu: ${ }^{39}$

a. Prinsip otonomi;

Prinip otonomi menekankan pada sikap seseorang untuk mengambil suatu tindakan atas kesadarannya tentang apa yang dianggapnya benar dan bersedia mempertanggungjawabkan keputusannya termasuk pula menanggung dampak yang timbul akibat keputusan tersebut.

b. Prinsip kejujuran;

Prinsip kejujuran tidak hanya dilakukan dalam kaitannya dengan hubungan kerja tetapi juga harus diimplementasikan dalam pemenuhan syarat-syarat perjanjian.

c. Prinsip tidak berbuat jahat dan prinsip berbuat baik;

Prinip ini pada intinya menekankan prinsip sikap moral yang baik dalam suatu perjanjian.

d. Prinsip keadilan;

Prinsip ini menuntut perlakuan yang sama atas hak dari para pihak dalam suatu perjanjian.

e. Prinsip hormat kepada diri sendiri.

Dalam kaitannya dengan kegiatan jual beli akun premium Spotify oleh pelaku usaha dalam situs belanja online atau online shop tampak adanya kecacatan dalam pembentukan kontrak diantara pelaku usaha dan pihak Spotify. Cacat kehendak (wilsgebreken atau defect of consent) adalah kecacatan dalam pembentukan kata sepakat dalam suatu kontrak atau perjanjian. ${ }^{40}$ Kondisi ini tidak selalu tampak pada suatu perjanjian, namun sering terjadi pada fase prakontrak yaitu saat para pihak mencapai

36 Umar, D. U. (2020). Penerapan Asas Konsensualisme Dalam Perjanjian Jual Beli Menurut Perspektif Hukum Perdata. Lex Privatum, 8(1).

37 Winarni, L. N. (2015). Asas Itikad Baik Sebagai Upaya Perlindungan Konsumen Dalam Perjanjian Pembiayaan. Jurnal Hukum, 2(2), 89-102.

38 Turisno, B. E. (2011). Etika Bisnis dalam Hubungannya dengan Transformasi Global dan Hukum Kontrak Serta Perbuatan Melawan Hukum. Masalah-Masalah Hukum, 40(3), 291-296.

39 Ibid.

40 Sukananda, S., \& Mudiparwanto, W. A. (2020). Akibat Hukum Terhadap Perjanjian yang Mengandung Cacat Kehendak Berupa Kesesatan atau Kekhilafan (Dwaling) di Dalam Sistem Hukum Indonesia. Justitia Jurnal Hukum, 4(1). 
kata "sepakat" tidak berdasarkan atas kehendak bebas. ${ }^{41}$ Pengaturan mengenai wilsgebreken atau defect of consent diatur dalam ketentuan Pasal 1321 KUHPer yang menentukan bahwa "tiada kata sepakat yang sah apabila sepakat itu diberikan karena kekhilafan, atau diperolehnya dengan paksaan atau penipuan."

Merujuk pada pemikiran Ridwan Khairandy dalam hubungannya dengan kemungkinan adanya unsur paksaan, kesesatan ataupun penipuan, para pihak tidak boleh mengambil keuntungan dengan tindakan yang menyesatkan terhadap salah satu pihak. ${ }^{42}$ Berkaitan dengan unsur penipuan, KUHPer menentukan bahwa "Penipuan merupakan suatu alasan untuk pembatalan perjanjian, apabila tipu-muslihat, yang dipakai oleh salah satu pihak, adalah sedemikian rupa hingga terang dan nyata bahwa pihak yang lain telah membuat perikatan itu jika tidak dilakukan tipu-muslihat tersebut", sebagaimana ditentukan dalam Pasal 1328 KUHPer. Terhadap penipuan ini tidak dipersangkakan, tetapi harus dibuktikan. ${ }^{43}$

Dalam ketentuan Pasal 1365 KUHPer, ditentukan bahwa "tiap perbuatan melanggar hukum, yang membawa kerugian kepada seorang lain, mewajibkan orang yang karena salahnya menerbitkan kerugian itu, mengganti kerugian tersebut". Ketentuan ini juga dikenal dengan istilah perbuatan melawan hukum atau dikenal juga dengan sebutan onrechtmatigedaad, dengan unsur-unsur sebagai berikut: ${ }^{4}$

a. adanya suatu perbuatan;

b. perbuatan tersebut melawan hukum;

c. adanya kesalahan dari pihak pelaku;

d. adanya kerugian bagi korban; dan

e. adanya hubungan kausal antara perbuatan dengan kerugian.

Unsur-unsur tersebut merupakan arti sempit dari perbuatan melawan hukum sebagaimana ditentukan dalam ketentuan Pasal 1365 KUHPer. Dalam perkembangannya, makna perbuatan melawan hukum semakin diperluas sejak tahun 1919 sebagai berikut: 45

"Perbuatan melawan hukum adalah berbuat atau tidak berbuat yang:

a. melanggar hak subjektif orang lain (hak yang ditentukan oleh undangundang);

b. bertentangan dengan kewajiban hukum si pelaku (kewajiban yang ditentukan undang-undang); dan

c. bertentangan dengan tata susila atau bertentangan dengan kepatutan, ketelitian, dan kehati-hatian yang seharusnya dimiliki seseorang dalam pergaulan dengan sesama warga masyarakat atau terhadap harga benda orang lain".

Hingga saat ini, suatu perbuatan dapat di katagorikan sebagai perbuatan melawan hukum apabila perbuatan tersebut memang melanggar undang-undang, bertentangan dengan hak orang lain, bertentangan dengan kewajiban hukum pelaku, bertentangan dengan kesusilaan, atau bertentangan dengan kepatutan dalam masyarakat, namun

\footnotetext{
${ }^{41} \mathrm{Ibid}$.

42 Winarni, L. N., loc. cit.

${ }^{43}$ Lihat: Pasal 1328 KUHPer.

${ }^{44}$ Astriana, W. (2020). Perlindungan Terhadap Pihak Ketiga dan Tanggung Jawab Notaris Atas Perbuatan Melawan Hukum Yang Dilakukan Para Pihak dan Notaris Dalam Perjanjian Sewa Menyewa (Studi Kasus Putusan Pengadilan Tinggi Nomor 59/PDT/2019/PT. BDG). Indonesian Notary, 2(3), 735-758.

${ }^{45}$ Asnawi, M. (2017). Masalah-Masalah Hukum, 46(1), 55-68. doi:10.14710/mmh.46.1.2017.55-68.
} 
demikian suatu perbuatan dianggap sebagai perbuatan melawan hukum ini harus tetap dipertanggungjawabkan berkaitan dengan unsur kesalahan. ${ }^{46}$

Perbuatan yang dilakukan oleh pelaku usaha yang dengan sadar menyepakati term and condition berkaitan dengan penggunaan paket family plan yang ditentukan oleh pihak Spotify dapat diinterpretasikan sebagai perbuatan melawan hukum, karena pihak pelaku usaha yang menjual akun premium suatu entitas seperti Spotify tersebut dengan sadar dan sengaja memilih pilihan paket family plan untuk kemudian dijual kembali ke orang lain yang belum tentu memiliki hubungan keluarga atau tinggal di alamat yang sama sebagaimana ditentukan dalam term and condition dari pihak Spotify. Unsur kesalahan dan kesengajaan yang dilakukan pelaku usaha dalam kegiatan jual-beli akun premium Spotify ini merupakan suatu perbuatan melawan hukum, yaitu penipuan (bedrog) yang dapat mengakibatkan suatu perjanjian dapat dibatalkan karena adanya cacat kehendak, yang dalam hal ini kata sepakat dicapai dengan adanya tipu-muslihat dari salah satu pihak, yaitu pihak pelaku usaha tersebut.

\subsection{Potensi Pelanggaran Terkait Penyebarluasan Karya Intelektual Melalui E- Commerce}

Kegiatan menjual akun premium suatu entitas seperti Spotify yang dilakukan oleh beberapa oknum pelaku usaha dalam situs belanja online atau e-commerce dapat dikategorikan sebagai suatu perbuatan melawan hukum. Merujuk pada pemikiran Yahya Harahap, perbuatan melawan hukum sebagaimana ditentukan dalam ketentuan Pasal 1365 KUHPer timbul akibat perbuatan orang. ${ }^{47}$ Artinya, perbuatan melawan hukum merupakan akibat perbuatan manusia yang ditentukan sendiri oleh undangundang. ${ }^{48}$ Terdapat 2 (dua) tolok ukur perbuatan melawan hukum yang merupakan akibat perbuatan manusia, yakni: 49

a. perbuatan manusia yang sesuai dengan hukum (rechtmatig, lawfull); dan

b. perbuatan manusia yang tidak sesuai dengan hukum (onrechtmatig, unlawfull). Merujuk pada tolok ukur tersebut, maka dapat diketahui mengenai bentuk perbuatan melawan hukum berupa pelanggaran pidana (factum delictum), kesalahan perdata (law of tort), atau bertindih sekaligus dengan delik pidana dengan kesalahan perdata. ${ }^{50}$ Mengenai hak untuk menuntut dalam perbuatan melawan hukum tidak memerlukan adanya somasi. Seseorang memiliki mengalami kerugian atas suatu perbuatan melawan hukum, memiliki hak untuk menuntut ganti rugi dengan mengajukan gugatan ganti rugi nyata dan kerugian immateriil. 51 Artinya, apabila terjadi perbuatan melawan

\footnotetext{
${ }^{46}$ Hassanah, H. (2016). Analisis Hukum Tentang Perbuatan Melawan Hukum Dalam Transaksi Bisnis Secara Online (E-Commerce) Berdasarkan Burgerlijke Wetboek Dan Undang-Undang Nomor 11 Tahun 2008 Tentang Informasi Dan Transaksi Elektronik. Jurnal Wawasan Yuridika, 32(1), 38-51. doi:http://dx.doi.org/10.25072/jwy.v32i1.88

47 Shanti Rachmadsyah, 2010, Doktrin Gugatan Wanprestasi dan PMH, Hukumonline.com, retrieved from: https://www.hukumonline.com/klinik/detail/ulasan/lt4c7639738d93d/doktrin-gugatanwanprestasi-dan-pmh, diakses pada 14 November 2020.

${ }^{48}$ Tanaya, V. (2013). Rekontruksi Asas Perbuatan Melawan Hukum (Onrechtmatigedaad) Dalam Gugatan Sengketa Konsumen. Asy-Syir'ah: Jurnal Ilmu Syari'ah dan Hukum, 47(1). DOI: http://dx.doi.org/10.14421/asy-syir'ah.2013.\%25x

${ }^{49}$ Ibid.

50 Ibid.

51 Shanti Rachmadsya, loc. cit.
} 
hukum, pihak yang mengalami kerugian dapat menuntutnya saat itu juga (action, claim, rechtvordering). 52

Dalam perkembangannya, tuntutan yang dapat diajukan atas perbuatan melawan hukum juga mengalami perkembangan dalam yurisprudensi. Tuntutan ganti rugi yang awalnya berupa ganti rugi dalam bentuk uang, kini dapat pula diajukan dalam bentuk pemulihan pada keadaan semula (in natura) untuk selanjutnya tuntutan berupa pernyataan pengadilan bahwa perbuatan itu merupakan perbuatan melawan hukum dengan atau tanpa disertai ganti rugi dan tuntutan agar hakim memerintahkan untuk melakukan atau tidak melakukan sesuatu..$^{53}$

Suatu entitas seperti Spotify mendapat perlindungan sebagai Merek berdasarkan ketentuan Undang-Undang Nomor 20 Tahun 2016 tentang Merek dan Indikasi Geografis (selanjutnya "UU Merek dan IG"). Merujuk pada ketentuan dalam Pasal 1 huruf a disebutkan bahwa:

"Merek adalah tanda yang dapat ditampilkan secara grafis berupa gambar, logo, nama, kata, huruf, angka, susunan warna, dalam bentuk 2 (dua) dimensi dan/atau 3 (tiga) dimensi, suara hologram, atau kombinasi dari 2 (dua) atau lebih unsur tersebut untuk membedakan barang dan/atau jasa yang diproduksi oleh orang atau badan hukum dalam kegiatan perdagangan barang dan/atau jasa."

Perlindungan hukum atas merek suatu entitas seperti Spotify bertujuan untuk membedakan barang dan/atau jasa yang diproduksi oleh orang atau badan hukum dalam kegiatan perdagangan barang dan/atau jasa.

Dalam perlindungan merek, terdapat model perjanjian yang memberikan peluang bagi orang atau badan hukum untuk menggunakan merek yang sama, yaitu Lisensi. Merujuk pada ketentuan dalam Pasal 1 huruf $r$ UU Merek dan IG ditentukan bahwa:"Lisensi adalah izin yang diberikan oleh pemilik Merek terdaftar kepada pihak lain berdasarkan perjanjian secara tertulis sesuai peraturan perundang-undangan untuk menggunakan merek terdaftar."

Perbuatan oknum pelaku usaha dalam situs belanja online atau e-commerce yang menjual akun premium suatu entitas dengan menyebutkan merek seperti Spotify dapat dikategorikan sebagai pelanggaran atas Merek. Entitas yang merasa dirugikan dengan perbuatan penggunaan suatu merek tanpa izin tersebut dapat mengajukan gugatan atas pelanggaran merek kepada oknum pelaku usaha tersebut, sebagaimana diatur dalam Pasal 83 UU Merek dan IG. Gugatan yang dapat diajukan berupa gugatan ganti rugi dan/atau penghentian semua perbuatan yang berkaitan dengan penggunaan Merek tersebut.

Dengan demikian, pihak Spotify dapat mengajukan tuntutan perbuatan melawan hukum dapat dilakukan secara langsung kepada pelaku usaha yang menjual akun premium dan memanfaatkan paket family plan tersebut. Tuntutan perbuatan melawan hukum dapat secara langsung diajukan saat seseorang mengalami kerugian atas suatu perbuatan. Tuntutan dapat diajukan berupa ganti rugi nyata dan kerugian immateriil. Sesuai dengan perkembangan yurisprudensi, tuntutan dapat juga dapat dalam bentuk pemulihan pada keadaan semula (in natura) dengan atau tanpa disertai ganti rugi dan tuntutan agar hakim memerintahkan untuk melakukan atau tidak melakukan sesuatu. Selain itu, oknum pelaku usaha yang memanfaatkan suatu merek entitas tanpa izin pun dapat dikategorikan sebagai suatu pelanggaran atas merek. Pihak entitas pemilik Merek

\footnotetext{
52 Tanaya, V. loc. cit.

53 Butarbutar, E. N. (2018). Asas Ne bis In Idem dalam Gugatan Perbuatan Melawan Hukum. Jurnal Yudisial, 11(1), 23-39.
} 
pun dapat mengajukan gugatan pelanggaran merek terhadap pihak lain yang secara tanpa izin menggunakan dan memanfaatkan suatu Merek tersebut.

\section{Kesimpulan}

Berdasarkan deskripsi dan analisis yang dilakukan, dapat disimpulkan bahwa salah satu model perjanjian yang melandasi penyebarluasan konten karya intelektual dalam e-commerce adalah perjanjian lisensi. Keberadaan perjanjian lisensi memberikan kewenangan kepada pihak lain untuk melaksanakan hak ekonomi daripada pemegang hak cipta atau pemilik hak terkait dengan jangka waktu tertentu disertai dengan kewajiban untuk membayar sejumlah royalti kepada pemegang hak cipta. Perbuatan yang dilakukan oleh pelaku usaha yang dengan sengaja dan sadar untuk menyepakati dan menyetujui term and condition yang ditentukan oleh suatu entitas seperti Spotify berkaitan dengan penggunaan langganan paket family plan dapat diinterpretasikan sebagai perbuatan melawan hukum sebagaimana diatur dalam ketentuan Pasal 1365 KUHPer.Perbuatan melanggar hokum terjadi karena pihak pelaku usaha tersebut menjual akun premium Spotify dengan sadar dan sengaja memilih paket family plan untuk kemudian dijual kembali walaupun oknum tersebut telah menyetujui persyaratan yang diajukan oleh pihak Spotify yaitu mengenai penggunaan oleh anggota keluarga dan ketentuan mengenai alamat yang sama. Adanya unsur kesalahan dan kesengajaan yang dilakukan oleh pelaku usaha tersebut merupakan suatu penipuan (bedrog) yang dapat mengakibatkan pembatalan atas suatu perjanjian karena adanya cacat kehendak yaitu dicapainya kata "sepakat" karena adanya tipu-muslihat dari salah satu pihak, yaitu pihak pelaku usaha. Selain itu, perbuatan oknum pelaku usaha dalam e-commerce yang menjual akun premium suatu entitas dengan menyebutkan merek seperti Spotify dapat dikategorikan sebagai pelanggaran atas Merek. Entitas yang merasa dirugikan dengan perbuatan penggunaan suatu merek tanpa izin tersebut dapat mengajukan gugatan atas pelanggaran merek kepada oknum pelaku usaha tersebut. Melihat fenomena tersebut, pihak Spotify sebagai salah satu contoh entitas penyedia layanan streaming perlu meningkatkan pengawasan dan memperketat sistem operasi agar mampu menyaring oknum yang menjual akun premium tersebut. Selain telah melanggar ketentuan yang ditetapkan pihak spotify, hal ini juga berpotensi menimbulkan masalah terkait dengan data pribadi para pengguna spotify yang dibeli melalui akun-akun online tersebut.

\section{Daftar Pustaka}

\section{$\underline{\text { Buku }}$}

Fajar, M \& Achmad, Y. (2013). Dualisme Penelitian Hukum Normatif \& Empiris. Yogyakarta: Pustaka Pelajar.

Fuady, D. M. (2014). Teori-teori Besar Dalam Hukum: Grand Theory. Prenada Media.

\section{Jurnal Ilmiah}

Aco, A., \& Endang, H. (2017). Analisis Bisnis E-Commerce pada Mahasiswa Universitas Islam Negeri Alauddin Makassar. Jurnal Insypro (Information System and Processing), 2(1).

Asnawi, M. (2017).Masalah-Masalah Hukum, 46(1), 55-68. doi:10.14710/mmh.46.1.2017.55-68.

Astriana, W. (2020). Perlindungan Terhadap Pihak Ketiga dan Tanggung Jawab Notaris Atas Perbuatan Melawan Hukum Yang Dilakukan Para Pihak dan Notaris 
Dalam Perjanjian Sewa Menyewa (Studi Kasus Putusan Pengadilan Tinggi Nomor 59/PDT/2019/PT. BDG). Indonesian Notary, 2(3), 735-758.

Butarbutar, E. N. (2018). Asas Ne bis In Idem dalam Gugatan Perbuatan Melawan Hukum. Jurnal Yudisial, 11(1), 23-39.

Devi, K. B. T. L., \& Dharmawan, N. K. S. Tanggung Jawab Pelaku Usaha Terhadap Konsumen Terkait Cacat Tersembunyi Pada Barang Elektronik Dalam Transaksi Online. Kertha Semaya: Journal Ilmu Hukum, 4(1), 1-14.

Endi Suhadi. (2017). Aspek Konsensualisme Dalam Penambahan Klausula Kontrak Tanpa Persetujuan Para Pihak. Jurnal Ilmiah Hukum Dan Keadilan, 4(1), 94-109. Retrieved from https:/ / ejurnal.stihpainan.ac.id/index.php/jihk/article/view/78

Fitriah, F. (2020). Perlindungan Hukum Bagi Konsumen Dalam Transaksi Jual Beli Melalui Media Sosial. Solusi, 18(3), 371-382. https://doi.org/10.36546/solusi.v18i3.305

Hassanah, H. (2016). Analisis Hukum Tentang Perbuatan Melawan Hukum Dalam Transaksi Bisnis Secara Online (E-Commerce) Berdasarkan Burgerlijke Wetboek Dan Undang-Undang Nomor 11 Tahun 2008 Tentang Informasi Dan Transaksi Elektronik. Jurnal Wawasan Yuridika, 32(1), 38-51. doi:http://dx.doi.org/10.25072/jwy.v32i1.88

Indah, C. (2010). Aspek Perjanjian Electronic Commerce Dan Implikasinya Pada Hukum Pembuktian Di Indonesia. Masalah-Masalah Hukum, 39(2), 172-184. doi:10.14710/mmh.39.2.2010.172-184.

Isnandya, E. R. (2020). Pembatalan oleh Hakim terhadap Akta Jual Beli yang Dibuat Berdasarkan Penipuan (Bedrog). Indonesian Notary, 2(3).

Muhtarom, M. (2014). Asas-Asas Hukum Perjanjian: Suatu Landasan Dalam Pembuatan Kontrak.

Nurwullan, S., \& Siregar, H. F. (2020, June). Asas Konsensualisme Dalam Penambahan Klausula Kontrak Berdasarkan Prinsip Itikad Baik. In Proceedings (Vol. 1, No. 1).

Sinaga, N. A. (2018). Peranan Asas-Asas Hukum Perjanjian Dalam Mewujudkan Tujuan Perjanjian. Binamulia Hukum, 7(2), 107-120, DOI: https://doi.org/10.37893/jbh.v7i2.20

Sukananda, S., \& Mudiparwanto, W. A. (2020). Akibat Hukum Terhadap Perjanjian yang Mengandung Cacat Kehendak Berupa Kesesatan atau Kekhilafan (Dwaling) di Dalam Sistem Hukum Indonesia. Justitia Jurnal Hukum, 4(1).

Supasti, N. K. (2014). Relevansi Hak Kekayaan Intelektual Dengan Hak Asasi Manusia Generasi Kedua. Jurnal Dinamika Hukum, 14(3), 518-527.

Tanaya, V. (2013). Rekontruksi Asas Perbuatan Melawan Hukum (Onrechtmatigedaad) Dalam Gugatan Sengketa Konsumen. Asy-Syir'ah: Jurnal Ilmu Syari'ah dan Hukum, 47(1). DOI: http:/ / dx.doi.org/10.14421/asy-syir'ah.2013.\%25x

Turisno, B. E. (2011). Etika Bisnis dalam Hubungannya dengan Transformasi Global dan Hukum Kontrak Serta Perbuatan Melawan Hukum. Masalah-Masalah Hukum, 40(3), 291-296.

Umar, D. U. (2020). Penerapan Asas Konsensualisme Dalam Perjanjian Jual Beli Menurut Perspektif Hukum Perdata. Lex Privatum, 8(1).

Winarni, L. N. (2015). Asas Itikad Baik Sebagai Upaya Perlindungan Konsumen Dalam Perjanjian Pembiayaan. Jurnal Hukum, 2(2), 89-102.

Wulandari, Y. S. (2018). Perlindungan Hukum bagi Konsumen terhadap Transaksi Jual Beli E-Commerce. Ajudikasi: Jurnal Ilmu Hukum, 2(2). 


\section{Disertasi}

Mantri, B. H. (2007). Perlindungan hukum terhadap konsumen dalam transaksi ecommerce (Doctoral dissertation, program Pascasarjana Universitas Diponegoro).

\section{Website}

Adi Fida Rahman, 2020, Cara Menikmati Netflix dari Berbagai Perangkat, Detik.com, Retrieved from: https://inet.detik.com/tips-dan-trik/d-3113004/caramenikmati-netflix-dari-berbagai-perangkat, diakses pada 10 November 2020.

Antara, 2020, Pandemi Covid-19, Spotify Umumkan Lonjakan Luar Biasa Jumlah Pengguna, Retrieved from: https://tekno.tempo.co/read/1400978/pandemicovid-19-spotify-umumkan-lonjakan-luar-biasa-jumlahpengguna/full\&view=ok, diakses pada 10 November 2020.

Bill Clinten, 2019, Paket Family Sering Disalahgunakan, Spotify pun Minta Data Lokasi, Kompas.com, retrieved from: https:/ tekno.kompas.com/read/2019/09/15/11080057/paket-family-seringdisalahgunakan-spotify-pun-minta-data-lokasi?page=all., diakses pada 12 November 2020.

2020, Pengakuan Penjual Akun Premium Netflix dan Spotify, Lebih Murah dari Resmi, Kompas.com, retrieved from: https://tekno.kompas.com/read/2020/06/26/14521357/pengakuan-penjualakun-premium-netflix-dan-spotify-lebih-murah-dari-resmi, diakses pada 13 November 2020.

Shanti Rachmadsyah, 2010, Doktrin Gugatan Wanprestasi dan PMH, Hukumonline.com, retrieved from: https://www.hukumonline.com/klinik/detail/ulasan/lt4c7639738d93d/doktr in-gugatan-wanprestasi-dan-pmh, diakses pada 14 November 2020.

Spotify, 2020, Apa itu Spotify? Retrieved from: https://support.spotify.com/id/article/what-is-spotify/, diakses pada 9 November 2020.

2020, Premium Family Terms, Retrieved from: https://www.spotify.com/id/legal/premium-family-terms/, diakses pada 12 November 2020.

Wahyunanda Kusuma Pertiwi, 2020, Marak Jual Beli Akun Netflix, Spotify dan Youtube Premium di Indonesia, Legalkah?, Kompas.com, Retrieved from: https:/ tekno.kompas.com/read/2020/06/26/13440677/marak-jual-beli-akunnetflix-spotify-dan-youtube-premium-di-indonesia-legalkah?page=all, diakses pada 12 November 2020.

\section{Peraturan Perundang-Undangan}

Kitab Undang-Undang Hukum Perdata.

Undang-Undang Nomor 11 Tahun 2008 Tentang Informasi dan Transaksi Elektronik Lembaran Negara Republik Indonesia Tahun 2008 Nomor 58, Tambahan Lembaran Negara Republik Indonesia Nomor 4843.

Undang-Undang Nomor 28 Tahun 2014 tentang Hak Cipta, Lembaran Negara Republik Indonesia Tahun 2014 Nomor 266, Tambahan Lembaran Negara Republik Indonesia Nomor 5599. 
Undang-Undang Nomor 20 Tahun 2016 tentang Merek dan Indikasi Geografis, Lembaran Negara Republik Indonesia Tahun 2016 Nomor 252, Tambahan Lembaran Negara Republik Indonesia Nomor 5953. 